\title{
THE VOICE OF SINGULARITY AND A PHILOSOPHY TO COME
}

\author{
SCHÜRMANN, KANT, AND THE PATHOLOGY OF BEING \\ Christopher P. Long
}

I am an object of myself and of my representations. That there is something else outside me is my own product. I make myself.... We make everything ourselves.

-Immanuel Kant, Opus Postumum, XXII, 82.

Installation and evasion, where being undergoes the pathetic divide between the universal that is a thesis and the singular that is given.

-Reiner Schürmann Broken Hegemonies, 488

At the very moment his ultimate sovereignty is secured, Agamemnon's voice trembles. He sees clearly the "heavy fate" that binds him, at once and irreducibly, to two laws - as King, he must sacrifice his daughter to calm the winds at Aulis, as father, he must protect his child. His voice trembles as one law is denied to allow the other to reign supreme. This is what he says:

For if this sacrifice, this virgin blood, stops the winds, it is right [ $\theta \dot{\varepsilon} \mu \imath \varsigma$ ] for them [his allies] to desire it with passion, most passionately [ó $\rho \gamma \hat{\alpha}$ $\left.\pi \varepsilon \rho ı \rho \gamma \hat{\omega} \sigma<\phi^{\prime}>\dot{\varepsilon} \pi \imath \theta v \mu \varepsilon \hat{\imath} v\right]$. May all be well. ${ }^{1}$

The poet's language captures the signature of Agamemnon's tragic denial. Aeschylus reduplicates the word óprí, which means at once violent emotion, anger and passionate suffering, and thus articulates the force endemic to the institution of the univocal law. This orgy of language expresses both the means and the manner in which the law is established: As the law of the patriarchy is installed "with passion," the law of the father is "most passionately" denied. ${ }^{2}$ This denial is amplified by the prefix $\pi \varepsilon \rho 1-$, which means "exceedingly," and so gives voice to a certain excess. This singular here, Iphigenia, is sacrificed in the name of a divine $\theta \dot{\varepsilon} \mu \iota \varsigma$ appealed to by a King set on consolidating his authority absolute. ${ }^{3}$ Yet the poet refuses to pass over this moment of rupture in silence. His language trembles and the tragic denial that institutes

PHILOSOPHY TODAY the law is exposed. In and through language, a rupture appears that undermines the ultimate authority of the patriarchal law.

\section{The Trace of a Denial}

In a 1763 text titled Der einzig mögliche Beweisgrund zu einer Demonstration des Daseins Gottes at the moment he attempts a positive articulation of the meaning of existence, Kant's voice trembles. There the nature of Dasein is determined at first by a distinction between the simple Position of a thing and that which is posited [gesetz] in relation to some other thing. Kant writes: "Existence is the absolute position [Position] of the thing and thus is distinguished from every predicate which as such is always posited [gesetz wird] merely with respect to some other thing." ${ }^{\prime 4}$ Immediately, however, Kant seems to collapse the distinction: "The concept of Position or Setzung is totally simple and on the whole identical with the concept of being in general." Here, Kant's voice can be heard to tremble; for the difference between Position and Setzung is elided by a disjunction that identifies the two. This disjunctive conjunction voices the trace of what Reiner Schürmann calls a "double comprehension of being" in Kant. ${ }^{6}$

Schürmann's engagements with Kant, both in his 1984 essay "Legislation-Transgression: Strategies and Counter-strategies in the Transcendental Justification of Norms" and in his magnum opus, Broken Hegemonies, are guided throughout by an attentive reading of the dynamic play between Position and Setzung in Kant, a play of language that is said to articulate two senses of being that shatter the autonomy of the transcendental subject, rendering it incapable of serving as the ultimate principle of legislative authority. In the complex and dynamic ways Position and Setzung are said in Kant, Schürmann discerns a tension between two senses of being that can be initially stated as follows: On the one hand, being is one of the categories through which the un-

SPEP SUPPLEMENT 2009 
derstanding gives rise to objects of possible experience; on the other hand, being is understood in a "pre-categorial" sense as pure givenness as such. Drawing on a remark Kant makes in the Critique of Judgment in which the term Position is used to designate "the representation of a thing with respect to our concept" and Setzung is used to point to the "thing in itself (apart from this concept)," Schürmann seeks to map these terms onto Kant's double comprehension of being by identifying Position with the thetic act that gives rise to existence as the second category of modality and Setzung with the pre-categorial apprehension of being as givenness. ${ }^{7}$

This terminological distinction, however, as Schürmann himself recognizes, vacillates as Kant's thinking shifts under the pressure of the Copernican turn in which the age old ontological question "What is being?" is at first subverted by the transcendental step back to the conditions for the possibility of experience, only then, in the second edition of the Critique of Pure Reason, to return with a vengeance that threatens to shatter the ultimate autonomy and thus authority of the transcendental subject. ${ }^{8}$ By attending carefully to the manner in which the dual comprehension of being comes to language in Kant, Schürmann is able to discern the tragic truth the Kantian critical project must deny if it is to succeed. Schürmann puts it this way:

Subjective spontaneity turns received being against thetic being. This is how the Kantian gesture that succeeds in instituting the modern referent remains, despite everything, faithful to the tragic truth, the truth of the conflict between the ultimates that have hold of us without recourse. Kant thematizes these as the impulse (of natality) toward autonomy, and then again as the impulse (of mortality) toward heteronomy. The first leads us to legislate universally. The second always returns us to the singular that occurs and is given outside of the universal, categorical law that the understanding declares. The differend between the conflictual strategies of being will turn transcendental logic into a broken imperative ontology. ${ }^{9}$

Kant's faithfulness to the tragic truth is only uncovered by a reading vigilantly attentive to what shows itself in language. Thus, even if, as this passage intimates and as Schürmann argues elsewhere, language is situated on the side of natality, autonomy, the universal, and the categorial, it nevertheless remains capable of articulating something of mortality, heteronomy, the singular, and givenness as such. The very trembling of language gestures to this capacity. Language can thus be heard to speak differently in those palpable moments when it encounters something of that which escapes its own subsumptive strategies.

\section{An Other Language}

Schürmann often identifies the subsumptive violence of predication with language and associates its universalizing function with the ontological trait of natality. Thus, he writes: "Fantasms install themselves as universals - thetic work proclaims them to be so, a work that is always accomplished by language." $"$ For Schürmann, this is the linguistic work of natality on which life itself, "nourished on common significations," depends: ${ }^{11}$ "we are lodged under the violence of the common, outside of which . . . there is no life." 12 The entire project of Broken Hegemonies can be understood as an attempt to expose the hegemonic fantasms under which each linguistic epoch wins a life for itself by maximizing the thetic reality it posits as ultimate even as it denies its own collusion in this thetic maximization. Schürmann puts it this way:

A fantasm is hegemonic when an entire culture relies on it as if it provided that in the name of which one speaks and acts. Such a chief-represented (hêgemôn) is at work upon the unspeakable singular when it calls it a part of the whole; hegemonies transform the singular into a particular. $^{13}$

Although the language of each epoch gives rise to its particular fantasm-ancient Greek posits the hegemony of the hen, medieval Latin that of natura, and modern German the hegemony of Selbstbewußtsein-the logic of ultimate referentiality remains fundamentally consistent: it is predicated on effacing the encounter with the singular from which the hegemonic principle itself is born.

Yet Schürmann does not oppose the positing of hegemonic principles by means of a determinate negation that would remain bound to

THE VOICE OF SINGULARITY 
the same thetic act by which the law is instituted. ${ }^{14}$ Rather, through an "analytic of ultimates," 15 he exposes the denial inherent in the institution of the very principles that make a common life possible. Schürmann deploys a topological methodology that seeks to uncover the place of this denial, the site at which the thetic thrust of natality encounters and attempts to camouflage the dispersive counterthrust of mortality: "Topology seeks to go back to the given, under the posited."16 This topological analytic of ultimates, however, does not permit natality, the orginary archic trait that "prompts us toward new commencements and sovereign commandments," to pair off with mortality, the originary dispersive trait that "wrests us from the world of such archic referents." 17 Natality and mortality do not consolidate into a unified system of oppositions.

However, Schürmann himself articulates these originary traits in oppositional terms, associating natality on the one hand with the universal, the conceptual and the violence of language, and mortality, on the other hand, with the singular, the given and an ineluctable silence. ${ }^{18}$ Nevertheless, the way the topological analytic of ultimates is performed in Broken Hegemonies opens a space for a different understanding of language in its relation to natality and mortality, one that Schürmann deploys but hardly thematizes. This other language is not subsumptive and apodictic, but rather attentive and apophantic. By attending to those moments of disruption expressed in and through language itself, something other than the subsumptive violence against the singular is shown to be at work in language. The apophantic dimensions of language, its capacity to articulate phenomena as they show themselves to be, animates Schürmann's topological analytic of ultimates, turning it into a

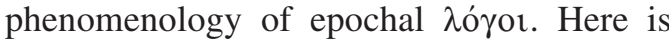
heard a kind of "legomenology" in which the things said in a given epoch themselves are taken as phenomenological clues to the originary denial upon which the ultimate referent of an epoch depends. ${ }^{19}$

Schürmann attends carefully to the language by which the professional philosophers of each epoch, functioning as what Husserl called "civil servants of humanity," institute and legitimize hegemonic fantasms. ${ }^{20}$ In so do-

\section{PHILOSOPHY TODAY}

ing, however, he uncovers the language of the differend - the very articulation of that irreconcilable legislative conflict between two legitimate laws whereby the sovereignty of one necessarily involves the subversion of the other. $^{21}$ The language of the differend gives voice to an unstable community of relation between natality and mortality that conditions human existence. It is heard in the poetic language of tragedy that refuses to endure denial in silence, but attempts to bring the conflict of ultimates itself to language. Despite his own deep skepticism about philosophical language, Schürmann teaches philosophy the poetic language of tragedy and in so doing, rehabilitates a philosophical thinking capable of a kind of "tragic knowledge" that refuses to collude in the delusion endemic to its own legislative tendencies. ${ }^{22}$ Indeed, Schürmann insists that "the differend is articulated in legislativetransgressive strategies that provide mortals with their condition of being, a broken condition that philosophers-those who know how to read-have never ceased to watch over." ${ }^{23}$ In his careful, provocative and sometimes fantastic readings, Schürmann articulates the differend that shows itself each time a law is posited as ultimate.

\section{Kant and the Transcendental Delusion}

Kant offers a singularly perspicuous site for an investigation into the way the differend between the singular given and the legislating impulse come to language; for Kant is the master legislator who, in decisively establishing the autonomy of self-consciousness as the hegemonic fantasm of the modern age, unwittingly gives voice to "the unsubsumable other against which spontaneity collides." 24 Schürmann articulates Kant's peculiar relation to the tragic double bind this way:

\footnotetext{
With full clarity, he sees a certain originary break through which the critical turn puts us, in the final instance, in a double bind. He then evades the pathetic condition he perceived and escapes to the terrains adjacent to the transcendental, at times the terrain of the thing-in-itself, at others the terrain of appearance. It will be necessary to ask oneself if, here again, Kant has not recognized, and then denied, an originary
}

SPEP SUPPLEMENT 2009 
pathein, a suffering which affects transcendental being. ${ }^{25}$

Schürmann pursues Kant's pathology of legislation first by exposing what he calls the "torments of autonomy" in which the autonomy of the transcendental subject is shown to be fractured at its core by "two incommensurable strategies within the same originarily transcendental freedom." ${ }^{26}$ The one, associated with the transcendental self, names the very spontaneity that serves as the condition for possible experience. This is constitutive freedom, the autonomy that posits the very laws that condition all cognition and action. The other conception of freedom, associated with the ego, does not of necessity conform to the rational will-it points to a willfulness deprived of rules. ${ }^{27}$ Schürmann describes the ego "as the inextirpable tendency to introduce the other, as a motive and means, right into the heart of reason." 28 The very possibility of moral action is itself predicated on an arbitrary will, pulled by impulses and desires, by "the murmur of alien, singular, solicitations," yet capable of freely choosing to conform to the moral law or of consciously embracing radical evil by subordinating itself to the motives of desire and legislating such subordinations as maxims. ${ }^{29}$ The autonomy of the transcendental self expresses the trait of natality, the autonomy of the ego that of mortality. Taken together, they point to the site of an ineluctable fissure in the attempt to ground cognitive, ethical and pragmatic legislation on the autonomy of the subject.

Yet Schürmann's reading of the torments of the autonomy of self-consciousness is in fact already informed by the suspicion that there is a deeper, more originary fissure at the core of Kant's thinking, a rupture over against which these torments, however disquieting, appear as mere symptoms. This suspicion is most clearly articulated in Schürmann's introduction to Part Three of Broken Hegemonies, entitled, "In the Name of Consciousness: The Modern Hegemonic Fantasm." There he writes:

Following the thread of an entirely coherent concatenation of arguments (even though it has escaped the attention of most commentators) from the precritical writings up to the Critique of Judgment, we will see that a conflict between two senses of being splits self-consciousness; that the referent from which the moderns expect supreme legislation produces, simultaneously and necessarily, its own transgression. ${ }^{30}$

To follow the thread of this argument, however, uncovers the manner in which the differend at work in all nomothetic legislation shows itself in language.

The first intimation of this originary conflict between two senses of being in Kant has already been heard in the pre-critical, 1763 Beweisgrund text. There Kant's voice trembles as he first articulates a difference between Position and the sort of Setzung associated with predication only then immediately to identify the two. ${ }^{31}$ Strangely enough, Schürmann does not point to this passage in the text, but rather to two other passages in which, he argues, the vocabulary of Setzung refers unequivocally to an originary givenness that precedes the thetic activity of the subject. Before turning to these specific passages, however, it is important to recognize that at least in the initial articulation of the meaning of Position in the Beweisgrund text, the cognate of Setzung refers not to originary givenness, but to those relations of predication by which something is posited [gesetz wird] with respect to something else. Such predications are closely associated with the relation things have to their properties over against which Kant wants to distinguish the simple concept of $\mathrm{Po}$ sition. ${ }^{32}$ By collapsing the difference between Position and Setzung here, Kant already implicitly opens the space for an another understanding of Setzung, one that extends beyond the positing endemic to predication. ${ }^{33}$

Schürmann locates precisely such a prepredicative apprehension of Setzung in Kant's discussion of possibility in the 1763 text. There Kant considers the formal conditions under which possibility itself is possible. He distinguishes between logical impossibility, which simply involves internal contradiction, and the vanishing of possibility which happens "when no matter or no datum is there to think." ${ }^{34}$ This allows Kant first to suggest the following: "If, then, all existence is denied, then nothing whatsoever is posited [so ist nichts schlechthin gesetzt], nothing at all is given [gegeben], no matter of anything to be thought upon, and all possibility vanishes en-

THE VOICE OF SINGULARITY 
tirely. ${ }^{35}$ Here, Kant seems to suggest: nichts gesetzt, nichts gegeben, nothing posited, nothing given; and when nothing is given, nothing can be thought and possibility itself disappears. Kant goes on to argue: "That there be some possibility and yet absolutely nothing actual, contradicts itself; for, if nothing exists, also nothing is given which would be thinkable there, and one would contradict oneself if one nevertheless pretends that something is possible." ${ }^{36}$ Drawing on these two sentences, Schürmann generates a poignant equation to illustrate how Kant consolidates the meaning of Setzung by identifying it first with the "given" and then by extending the meaning of the given to existence. Thus, Schürmann writes: "Setzung = Gegebensein $=$ Dasein." ${ }^{37}$

The articulation of Setzung in the pre-critical 1763 text is thus said to gesture to an understanding of being that precedes the thetic activity of the subject. Schürmann himself identifies the relation between saying and being expressed here with Aristotelian logic, "where ways of saying reflect, without thereby creating a problem, ways of being." 38 Schürmann's own topological analytic of ultimates itself trades on something like the Aristotelian recognition that the ways things are said express something of the truth of being. Thus, by attending carefully to the way "positing" is said in Kant, Schürmann is able to uncover a pre-categorial apprehension of being at work in the 1763 Beweisgrund text. This other, non-thetic sense of positing and with it the sense of being as givenness is then pursued into the text of the Critique of Pure Reason where, under the pressure of the Copernican turn, there appears a "terminological chiasmus" between Position and Setzung that articulates the shifting ontological ground on which the transcendental project depends. ${ }^{39}$

In turning to the thetic activity of the transcendental subject in order to secure the conditions for the possibility of experience, Kant trades on and yet covers over the originary sense of being as extrinsic givenness, thus rendering all givenness intrinsic under the subjective conditions of sensibility. ${ }^{40}$ Yet, for Schürmann, the Copernican turn, however radical, "cannot disown a certain understanding of being." ${ }^{41}$ The sense of being as extrinsic givenness and articulated in the 1763 text by cognates of Setzung, remains operative in the

\section{PHILOSOPHY TODAY}

Critique of Pure Reason, although there Position rather than Setzung expresses the precategorial sense of being as givenness.

Schürmann locates this terminological chiasmus in two texts from the 1787 second edition of the Critique of Pure Reason where Setzung and its cognates come to designate the categorial sense of being that results from the positing activity of the mind, whereas Position is said to gesture to extra-mental being as givenness. First, in the discussion of sensibility in the Transcendental Aesthetic, Kant repeatedly deploys the cognates of setzen to designate the manner in which the mind affects itself by its own capacity for sensible intuition. Thus, Kant writes:

\footnotetext{
Now that which, as representation, can precede any act of thinking something is intuition and, if it contains nothing but relations, it is the form of intuition, which, since it does not represent anything except insofar as something is posited [gesetzt] in the mind, can be nothing other than the way in which the mind is affected by its own activity, namely this positing [dieses Setzen] of its representation, thus the way it is affected through itself. ${ }^{42}$
}

Here, gesetzt and setzen articulate the self-affective activity of the mind. They point not to being as pure givenness, but to the mind's receptive capacity under the subjective condition of sensibility. The repetition of cognates of Setzung in this passage expresses intrinsic rather than extrinsic givenness. ${ }^{43}$ The Copernican turn has thus turned the meaning of Setzung. Although it retains here a sense of givenness, it no longer points to the precategorial givenness of being, but to the selfaffective activity of the mind by which it gives itself representations. Indeed, if the transcendental project is to succeed in uncovering the $a$ priori conditions for the possibility of experience, it must deny the very possibility of a givenness outside the purview of the selfaffective activity of the subject.

Yet Schürmann's analysis exposes this denial by attending to the decussating senses of Setzung in order to articulate a tension in the meaning of givenness Kant somehow recognizes but nevertheless shrouds. Thus, in a poignant moment at the end of the first step of the transcendental deduction in which Kant at-

SPEP SUPPLEMENT 2009 
tempts to abstract from sensibility in order to uncover the conditions for the possibility of the understanding, ${ }^{44}$ he admits the following:

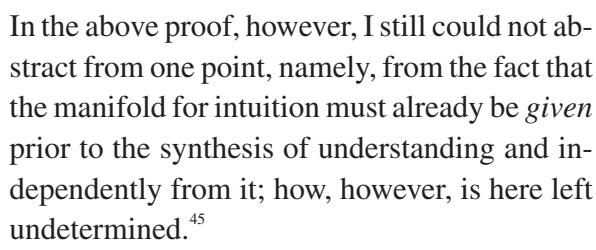

Schürmann reads this as a gesture to another sense of givenness, here intimated only to be left undetermined; the very question as to how what is given in intuition is itself given to intuition remains inaccessible. And yet, in the shifting meaning of Setzung something of an originary givenness, of an irreducible suffering, comes to language. Schürmann puts it this way: "These problems are knotted together in affection. It is in affection that position [i.e., Setzung] now turns aside from givenness and that makes the regime tremble."46

Yet, even in the Critique of Pure Reason, where Setzung and its cognates articulate the manner in which all givenness must run necessarily through the subjective conditions of sensibility, another sort of givenness comes to language in a second text to which Schürmann appeals as he attempts to hear in the vacillating meaning of Position and Setzung a denial of the meaning of being as givenness. In the section entitled On the Impossibility of an ontological proof of God's existence, Kant famously claims: "Being is obviously not a real predicate, i.e., a concept of something that could add to the concept of a thing. It is merely the Position of a thing or of certain determinations in themselves." 47 In a footnote to his 1984 text on legislation that anticipates the deeper reading of Kant pursued in Broken Hegemonies, Schürmann appeals to these famous Kantian sentences in order to insist: "Positing' does not mean here the self-instituting of a supreme ground but the fact that in experience something is being experienced. Positedness means facticity. It enters language through the copula." 48 Schürmann thus reads the term Position in Kant's discussion of the ontological proof in the Critique of Pure Reason as gesturing to extrinsic being as pure givenness that precedes all operations of the transcendental mind. ${ }^{49}$ Position names here what Setzung named in the 1763 text: the extrinsic givenness of being. Even here, however, a strict terminological distinction does not hold, for in analyzing the sentence "God is omnipotent," Kant insists that it contains two concepts, God and omnipotence, while "the little word 'is' is not a predicate in it, but rather only that which posits [setzt] the predicate in relation to the subject." ${ }^{50}$ If positedness means facticity here and comes to language through the copula, it does not settle squarely into the terminological distinction between Position and Setzung, for both terms seem ambiguously capable of pointing to the categorial and pre-categorial senses of being. Kant's language here again trembles. Schürmann himself insists that no definite terminological distinction between Position and Setzung is established until, in the Critique of Judgment, Kant returns to the question of the possible in relation to the actual in order to claim that "the former [namely, the actual] signifies only the Position of the representation of a thing with respect to our concept and, in general, our faculty for thinking, while the later [namely, the actual] signifies the Setzung of the thing in itself (apart from this concept)." ${ }^{51}$ Here the terminological grounds have shifted again, and Position names categorial, intrinsic being, while Setzung names extra-mental being as givenness apart from the concept.

In this articulation of Setzung, which is said to point here to an actuality outside the concept, Schürmann hears the echo of an originary suffering on which all transcendental positing depends. He writes:

\begin{abstract}
Position emphasizes, then, the relation of a conceived representation to the understanding, and hence, the possible; Setzung emphasizes the relation to sensibility of the material one suffers, and hence the actual. Thus the singular is recognized in its contingency and randomness. ${ }^{52}$
\end{abstract}

Attending to the ambiguity of being voiced in the ambiguity of language at play in the various senses of Position and Setzung, Schürmann brings the agony of Kantian theticism to language, thus giving voice to the "pathetic condition of being" Kant is said to have "seen clearly" and insistently denied. ${ }^{53}$

THE VOICE OF SINGULARITY 


\section{The Logic of Denial}

If in the Critique of Pure Reason, the ambiguous play of Position and Setzung gives voice to the manner in which an obstreperous givenness, despite all evasion, intrudes upon transcendental self-consciousness from without, the fundamental yet enigmatic distinction between the I-think and the I-am in Kant exposes transcendental self-consciousness to singularity from within. Schürmann traces the logic of Kantian denial to the site of this distinction. A brief account of the play between the I-think and the I-am in Kant articulates a tension that must be denied if the transcendental subject's ultimate legislative authority is to be secured. In articulating the manner in which singularity at once intrudes upon the subject from without and shatters it from within, Schürmann's reading of Kant allows us to discern another language of natality, one that is not simply subsumptive in nature, but also capable of bringing to expression a kind of tragic knowledge vigilantly attuned to the violence of its own operation.

Toward the end of the transcendental deduction, in $\S 25$, Kant returns to the original synthetic unity of apperception in which, he says, "I am conscious to myself not as I appear to myself, nor as I am in myself, but only that I am. This representation is a thinking, not an intuiting." ${ }^{54}$ According to Schürmann, this simple awareness that I am cleaves heart of transcendental spontaneity. ${ }^{55}$ This can be heard in an enigmatic and poignant note found in the middle of the section in which Kant writes: "The I think expresses the act [Actus] of determining my existence. The existence is thereby already given, but the way in which I am to determine it, i.e., the manifold that I am to posit in myself [in mir setzen solle], is not yet thereby given. ${ }^{, 56}$ Here the term setzen remains firmly situated within the transcendental apparatus insofar as it is associated with the way the mind gives itself the intuitions according to which something may be cognized. Yet Kant here seems to open the space in which to think an existence apart from what is given in intuition, that is, apart from the transcendental conditions under which experience first becomes possible. This existence is the simple awareness that I-am, itself neither noumenal nor phenomenal. ${ }^{57}$ This awareness of the I-am

\section{PHILOSOPHY TODAY}

seems to escape the productive powers of the transcendental subject, and yet, there it is. The other strategies of evasion Kant deploys to cover over this sort of insistent givenness-to declare it noumenal and thus outside scope of the transcendental project or to crush it under the thetic regime of subjective spontaneityremain unavailable, for in the I-am, an irreducible awareness of my own singularity announces itself. With the I-am, the I-think encounters itself as singular. Schürmann puts it this way: "if its nature is that it 'determines my existence,' then the I-think will have to be adjoined to an indeterminate givenness as equioriginary. The I-am singularizes the I-think, the universal legislator." ${ }^{88}$

Transcendental legislation shows itself here as pathological; for it remains conditioned by an irreducible givenness, a pathos, that at once escapes and makes possible the legislative spontaneity of the transcendental subject. ${ }^{59}$ The subject is thus exposed to a suffering it did not make and cannot escape. According to Schürmann, Kant sees this "with full clarity," but then denies it: "The transcendental critique recognizes the other that places us at its mercy, but it denies it as soon as it recognizes it." ${ }^{60}$ But Kant is no Agamemnon; for Agamemnon unequivocally recognizes the double bind in which he is situated. He says explicitly:

\footnotetext{
Heavy is my fate if I do not obey, but heavy too, if I slaughter my daughter, delight of my house, by maiden sacrifice, staining these father's hands with rivers of blood beside the alter. What of these things is without evils? ? $^{61}$
}

Kant's recognition is neither seen with such clarity nor voiced with such urgency. Schürmann himself admits that the tragic double bind that conditions the hegemonic fantasm of modernity is heard not so much in what Kant explicitly says, as in the vehemence by which the sense of being as givenness is denied. ${ }^{62}$ Yet even this suggests perhaps too much, for the Kantian denial of singularity itself comes to language precisely as Kant so powerfully articulates the legislative thrust of transcendental subjectivity. The very positing of the ultimate authority of the subject brings the singular to language. Here, perhaps, we are not dealing with recognition and denial, but, to use the Freudian vocabulary, with a pre-con-

SPEP SUPPLEMENT 2009 
scious awareness of the conflict and its repression. ${ }^{63}$ Freud develops his understanding of the unconscious from the theory of repression in which an idea that is, for whatever reason, repressed, remains both inaccessible to consciousness and yet effective. ${ }^{64}$ Some such repressed ideas are said to be 'unconscious' when they remain ultimately inaccessible to consciousness, having been kept from consciousness by continuing pressure, others, however, are said to be 'preconscious' when, under certain conditions, they are capable of becoming conscious. ${ }^{65}$ If these Freudian distinctions are mapped on to Schürmann's reading of Kant, perhaps it is possible to say that in the pre-critical writings and in the first edition of the Critique of Pure Reason, the sense of being as givenness and with it the irreducible encounter with singularity operate unconsciously in Kant. The repressed conflict between two senses of being is heard, however, in the way Kant's voice trembles as he articulates the nature of existence and its relation to positing. Thus, although the trace of that other sense of being as givenness comes to language here, it remains inaccessible to Kant. With the Copernican turn, however, and more specifically, with the second edition of the Critique of Pure Reason, where Schürmann insists that Kant took "a step forward, and a giant leap at that, toward an abyss traversing being itself," Kant encounters something irreducibly given that conditions the legislative authority of the subject but is not produced by it. ${ }^{66}$ The sense of being as pure givenness threatens to undermine the entire critical project. It thus must be repressed by a continuous pressure that comes to language at certain critical moments - in the distinction between the I-think and the I-am, in the repetitive deployment of cognates of Setzung in describing the subjective conditions under which intuitions are given, and in the articulation of the meaning of existence as Position in the section dealing with the proof for the existence of God. Schürmann's topological legomenology itself brings these moments to language in such a way that they can no longer be denied to consciousness. Thus, Schürmann's analytic of ultimates here uncovers a pre-conscious awareness in Kant of an originary conflict that must be repressed if the legislative authority of the transcendental subject is to be securely established and legitimated. Translating psychoanalytic repression into the language of denial, Schürmann writes:

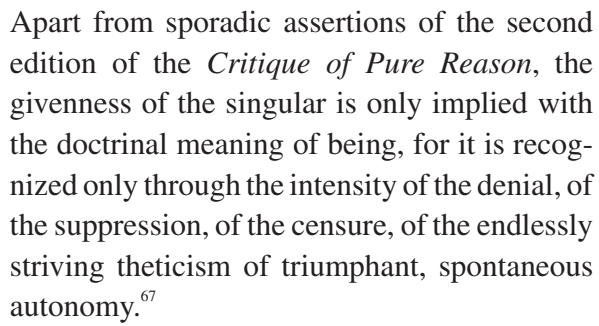

Apart from sporadic assertions of the second edition of the Critique of Pure Reason, the givenness of the singular is only implied with the doctrinal meaning of being, for it is recognized only through the intensity of the denial, of the suppression, of the censure, of the endlessly striving theticism of triumphant, spontaneous autonomy. ${ }^{67}$

Yet by tracing the topology of this suppression, Schürmann brings to language a way of thinking that can no longer abide the repression of the originary conflict. In so doing, however, he practices a way of philosophical saying that is capable of critically engaging the manner in which language colludes in the violence of the common on which life itself depends. $^{68}$

\section{The Voice of Singularity and the Philosophy-to-Come}

Schürmann's topological legomenology models a way of thinking and performs a philosophical saying capable of doing a certain justice to the suffering of the singular. Here the genitive is both subjective and objective, the singular suffers and is suffered-the encounter with singularity upon which life depends always operates in the middle voice. This is the ambiguous voice of singularity, the tremor of mortality heard in and through the language of natality. Here the language of natality is heard to involve more than the violent imposition of the subject upon the object, the forceful suppression of the singular under universal predicates that render it particular. Rather, the apophantic dimensions of the language of natality itself brings to expression the voice of the singular, irreducible and insistent, that irrepressibly operates in all our attempts to speak and act together in meaningful ways. ${ }^{69}$ If Schürmann names the condition that fractures every referent posited as ultimate "singularization to come," associating it with the ontological trait of mortality, perhaps the thinking that remains assiduously attuned to the manner in which this fracture comes to language despite all attempted repression could be associ-

THE VOICE OF SINGULARITY 
ated with natality and called a "philosophy to come" in which the voice of singularity is heard to express an irreducible otherness that holds us accountable and opens us always to new possibilities for community. ${ }^{70}$

A philosophy to come would then involve what might be called "mortal natality" and its chiasmus, "natal mortality." "Mortal natality" names the manner in which natal habits of thinking, acting and speaking not only refuse to cover over and repress the conditions of their own operation, but also open themselves to the possibilities that come to language at the site of the encounter with singularity. The mortality of natality thus would not forsake the common altogether, but would inject every attempt to enter into community with others with a dimension of openness that would render it inherently unstable and thus always in need of critical re-articulation. Yet if mortal natality names the condition under which a philosophy-to-come would need to relate itself critically to each constellation of community in which it finds itself embedded, natal mortality names the condition under which the singular, despite its ineffable unicity, comes nevertheless to language in a way that can be heard to hold all such critical re-articulations to account. "Natal mortality" points to the manner in which death itself refuses mute silence but continually comes to language with an urgency that can be neither repressed nor denied. Indeed, the natality of mortality infuses life with an insistent injunction to respond to the voice of singularity as the site of an ongoing, asymmetrical dialogue where new, more just, beginnings not only become possible, but insistently necessary.

\section{ENDNOTES}

1. Aeschylus, Agamemnon, trans. J. D. Denniston, and Denys Lionel Page (Oxford: Clarendon Press, 1960), 214-17.

2. The Greek dative is capable of expressing both the means by which something is done and the manner in which it is done. See Herbert Weir Smyth, Greek Grammar (Cambridge, MA: Harvard University Press, 1956), 346-48.

3. For a detailed interpretation of the manner in which Agamemnon's authority is established and the larger political implications of his tragic denial, see Christopher P. Long, "The Daughters of Métis: Patriarchal Dominion and the Politics of the Between," The Graduate Faculty Philosophy Journal 28, no. 2 (2007): 72-76.

4. Immanuel Kant, Kant's Gesammelte Schriften (Berlin: G. Reimer, 1902), II.73.

5. Ibid

6. Reiner Schürmann, Broken Hegemonies, ed. John Sallis, trans. Reginald Lilly (Bloomington: Indiana University Press, 2003), 483.

7. For the passage from the Critique of Judgment, see Immanuel Kant, Kritik Der Urteilskraft, (Hamburg: Felix Meiner Verlag, 1990), §76, 340. For Schürmann's attempt to map these terms onto the distinction between categorial and precategorial being, see Broken Hegemonies, 483. There Schürmann opts to translate Position as "thesis," and Setzung as "position." In what follows, however, the German terms are simply re- tained so that the difference to which they give voice may be more easily discerned and tracked in Kant.

8. Schürmann suggests, contrary to Heidegger in Kant and the Problem of Metaphysics, that the revisions Kant made to the Critique of Pure Reason between its first and second edition, when read with a view not exclusively toward the imagination, but by examining all of Kant's statements concerning being, mark not a retreat from the temporal understanding of being, but a decisive step toward the other, non-categorial sense of being as givenness that threatens to undermine the ultimate authority of transcendental self-consciousness. See Broken Hegemonies, 482. Cf., Martin Heidegger, Kant and the Problem of Metaphysics, trans. Richard Taft (Bloomington: Indiana University Press, 1990), §31, 110ff.

9. Broken Hegemonies, 483.

10. Ibid., 44. Schürmann understands conceptual thought as parasitic on language. He insists, for example, that "no thought, however, has ever resisted being carried away by its own language. Far from mastering a language, concepts live on it: they are born of words" (ibid., 4). That language does not dissolve into concepts means that it is capable of expressing more than the merely conceptual.

11. Ibid., 17.

12. Ibid., 22. "Thus to the extent that, to live, it is necessary to speak and act, to understand and think,

\section{PHILOSOPHY TODAY}


we will never extricate ourselves from poses and positions assumed, from theses put forth, and stops that are posited.... We will never extricate ourselves from legislative maximizings" (ibid., $345)$.

13. Ibid., 7.

14. Ibid., 622. Schürmann here insists upon a distinction between negation (Verneinung) and denial (Verleugnung): "Negating norms is a metaphysical operation that depends on a prior thetic act. On the other hand, denying a knowledge involves no such precursory normative thesis." Drawing on this distinction, he goes on to establish the difference between "destitution," which describes a fantasm that has lost its force of law, and "diremption," which "signifies the loss of every hegemony" (ibid., 623).

15. Ibid., 6-7, 9.

16. Ibid., 348. For an excellent account of Schürmann's topological analytic of ultimates, see Reginald Lilly, "The Topology of Des Hégémonies Brisées," Research in Phenomenology 28 (1998): 230-38.

17. Broken Hegemonies, 624. Another poignant formulation: "Once again, a summary of these pages would not be wrong in seeing in them a testing of a suspicion, namely, that the other of life does not fit in well with it; that their discord has always been known to us, however confusedly; that death joins life without, however, forming a tandem with it, that it does not reflect life symmetrically nor oppose it with a determinate negation" (ibid., 23).

18. Such oppositions are posited and denied in the General Introduction to Broken Hegemonies, see specifically, ibid., 18-36.

19. The term "legomenology" grows out of a reading of Aristotle that emphasizes the manner in which he takes the things said, $\tau \grave{\alpha} \lambda \varepsilon \gamma$ ó $\mu \varepsilon v \alpha$, themselves as phenomena that lend insight into the nature of things. For a detailed discussion of this dimension of Aristotle's thinking, see, Christopher P. Long, "Saving Ta Legomena: Aristotle and the History of Philosophy," The Review of Metaphysics 60 (2006): 247-67. The term appears in print for the first time in Long, "The Daughters of Métis," 68. It is developed in more detail in my forthcoming book, The Saying of Things: The Nature of Truth and the Truth of Nature in Aristotle.

20. Schürmann appeals to Husserl's statement in the Krisis in order to indict professional philosophers for their collusion in the uncritical nomothetic legislation of hegemonic fantasms. See Edmund Husserl, Die Krisis Der Europaeischen
Wissenschafen Und Die Transzendentale Phenomenologie (The Hague: Nijhoff, 1954), 15. Rodolphe Gasché, drawing on Schürmann's insistence that to understand a philosopher, one must seek the initial experience that "roused him to think" (Broken Hegemonies, 13), suggests that perhaps Schürmann's own thinking was guided by and remained concerned throughout with his experience with professional philosophers in the United States who were unwilling to turn their philosophical focus on the extent to which they too collude in the institution and legitimation of absolute ultimates. Gasché, "Hegemonic Fantasms," Research in Phenomenology 35 (2005): 312.

21. Schürmann says that "the differend, in its place of emergence, expresses a conflict between the thesis of the same and the non-thetic other, the conflict of ultimates." See Broken Hegemonies, 32. JeanFrançois Lyotard puts the meaning of the differend this way: "As distinguished from a litigation, a differend [différend] would be a case of conflict, between (at least) two parties, that cannot be equitably resolved for lack of a rule of judgment applicable to both arguments. One side's legitimacy does not imply the other's lack of legitimacy. However, applying a single rule of judgment to both in order to settle their differend as though it were merely a litigation would wrong (at least) one of them (and both of them if neither side admits this rule)." Jean-Franðcois Lyotard, The Differend: Phrases in Dispute, trans. Georges Van Den Abbeele (Minneapolis: University of Minnesota Press, 1988), xi. Schürmann uses the term to name the site where the singular that refuses particularization comes into conflict with the universal that seeks to set things in order.

22. Broken Hegemonies, 622.

23. Ibid., 34, my emphasis. Gasché puts this point beautifully when he writes: "This critique of philosophy is not separable from its apology. Broken Hegemonies is the extraordinary document of a philosophical thought in conflict with itself-of philosophical thought thinking against itself in the name of philosophical thinking." See Gasché, "Hegemonic Fantasms," 312.

24. Broken Hegemonies, 484. Schürmann's account of the institution of the modern fantasm of self-consciousness begins with Luther, who "recognized, circumscribed, and resolutely occupied the site upon which every thought process and every conceptual strategy of the next four centuries were to work." See Broken Hegemonies, 353. Despite this bold claim, Schürmann unequivocally locates the

THE VOICE OF SINGULARITY 
institution of the modern fantasm of self-consciousness in Kant. See Broken Hegemonies, 355.

25. Schürmann, Broken Hegemonies, 483.

26. Ibid., 480.

27. Ibid., 469, 80.

28. Ibid., 473.

29. Ibid., 471. Schürmann points to the discussion of radical evil in Die Religion innerhalb der Grenzen derbloßen Vernunft in which Kant identifies three human predispositions: (1) to animality, as living (2) to humanity, as living and rational, and (3) to personality as rational and accountable, all of which are said to "relate immediately to the ability to desire and the exercise of the arbitrary will [Willkür]" (AA, VI.26-8). Schürmann focuses on the fact that Kant does not trace evil back to selflove, but locates its root in the relation between the rational will and the arbitrary will. This is where Kant "introduces heteronomy right into the general function of reason." See Broken Hegemonies, 472. For his part, Kant says: "The wickedness (vitiosita, pravitas) or, if you like, the corruption (corruptio) of the human heart is the tendency of the arbitrary will to maxims which neglect the incentives arising from the moral law in favor of others (that are not moral)" (AA, VI.30).

30. Broken Hegemonies, 355. Of course, one commentator who decidedly did not allow this ontological distinction to escape his attention is Heidegger. Schürmann seems to borrow heavily from some of the core insights of Heidegger's Kants These über das Sein, although he nowhere sites this essay in his discussion of Kant. Nevertheless, it is Heidegger who identifies the meaning of being for Kant as positing and who first maps out the contours of the itinerary Schürmann will follow. Heidegger traces Kant's thesis concerning being from the pre-critical 1763 text on the proof of God's existence to the Critique of Pure Reason where the thesis that being is positing finds bold expression in the text on the Impossibility of an Ontological Proof and in the Postulates of Empirical Thought in General. He then gestures to section 76 of the Critique of Judgment, where, he says, "in order for the object to be cognized as actual, it requires affection from the senses." Martin Heidegger, "Kants These Über Das Sain," in Wegmarken, ed. Friedrich-Wilhelm von Herrmann (Frankfurt am Main: Vittorio Klostermann, 1976), 470. Finally, Heidegger returns to the Amphiboly of Concepts of Reflection in the Critique of Pure Reason to trace a new step

\section{PHILOSOPHY TODAY}

in Kant's interpretation of being, a step that involves the "reflection on reflection" where being as positing is fit into the structure of human subjectivity. For an interesting discussion of this aspect of Heidegger's reading of Kant, see Avery Goldman, "The Metaphysics of Kantian Epistemology," Proceedings of the American Catholic Philosophical Association 76 (2002): 239-52. Goldman shows there the manner in which Heidegger's approach to Kant in the These Über Sein is designed to show the presuppositions that underwrite the critical project itself. To this extent, Heidegger's and Schürmann's projects dovetail, for Schürmann's attempt to articulate an understanding of being as pure givenness is itself a way of uncovering the irreducible condition for the possibility of the critical project itself, a condition covered over by tragic denial. A comparative interpretation of Heidegger and Schürmann's reading of section 76 of the Critique of Judgment would illustrate how Heidegger holds firm to sensibility as the prior source of the critical project, while Schürmann identifies a givenness that precedes sensibility as the ineluctable condition the critical project must deny if it is to succeed.

31. Kant, AA, II.73.

32. Jaakko Hintikka suggests that Kant introduces the term setzen here and in the analogous passage from the Critique of Pure Reason, A 598/B 626, because he has "a desire to have a term which sits more happily with the cases in which 'is' apparently has a merely predicative function." "Kant on Existence, Predication, and the Ontological Argument," in The Logic of Being: Historical Studies, ed. Simo Knuuttila and Jaakko Hintikka (Dordrecht, Holland: D. Reidel, 1986), 257.

33. Although Hintikka finds a distinction between absolute and relative positing expressed in the Beweisgrund text, he insists that "Kant clearly thinks of the 'is' of predication (the copula) and the 'is' of existence as two uses of the same notion." Using the Frege-Russell thesis that 'is' is ambiguous in multiple ways, Hintikka maps the notion of relative positing in Kant, that is, positing something in relation to something, onto the "is" of predication; absolute positing, on the other hand, seems to map onto the "is" of existence. Yet, Hintikka thinks these two different senses of 'is' are not held distinct in Kant. See, Ibid., 258-59.

34. Beweisgrund, AA, II.78.

35. Ibid.

36. Ibid.

37. Broken Hegemonies, 486. 
38. Ibid.

39. Ibid., 672n154.

40. According to Schürmann, Kant trades on the originary sense of being insofar as he insists that the critical project presupposes, not merely a negative, but also a positive conception of the noumenon. This positive conception of the noumenon is heard in the preface to the second edition of the Critique of Pure Reason, where Kant insists upon the difference between cognition and thinking in order to open the space by which to think things in themselves. If this were not possible, Kant says, "there would follow the absurd proposition that there is an appearance without anything that appears" Immanuel Kant, Kritik Der Reinen Vernunft (Hamburg: Meiner Verlag, 1990), Bxxvi-xxvii. This appeal to appearance, Schürmann suggests, covers over the irreducible sense of being as givenness: "The force of the denial is obvious in the sleight of hand played upon appearance. From the pure event of appearing (in the infinitive sense), it is reified into that which appears (in the nominative sense)" (Broken Hegemonies, 492).

41. Reiner Schürmann, "Legislation-Transgression: Strategies and Counter-Strategies in the Transcendental Justification of Norms," Man and World 17 (1984): 372.

42. Kant, Kritik Der Reinen Vernunft, B67-68.

43. Reading the rest of this passage (B67ff.), Schürmann recognizes that "in the space of ten lines, the verb setzen occurs there five times. It designates (1) the intuition in internal sense as the investment (besitzen, ibid.) of that sense with relations; (2) an act concerning, not the thing in itself, but representation in its temporality (die Zeit, in die [sic] wir diese Vorstellungen setzen); (3) affection not through extrinsic givenness, but intrinsic givenness; time is that through which the mind affects itself (die Art, wie das Gemüt durch eigene Tätigkeit, nämlich dieses Setzen seiner Vorstellung, mithin durch sich self affiziert wird)" (Broken Hegemonies, 672n154).

44. For a discussion of the manner in which the deduction proceeds by two-steps, see Christopher P. Long, "Two Powers, One Ability: The Understanding and Imagination in Kant's Critical Philosophy," The Southern Journal of Philosophy 36 (1998): 234-36. See too, Dieter Henrich, "The Proof Structure of Kant's Transcendental Deduction," Review of Metaphysics 22 (1969): 640-59.

45. Kant, Kritik Der Reinen Vernunft, B145.
46. Broken Hegemonies, 488. Recall that Schürmann translates Setzung as "position," see ibid., 483.

47. Kant, Kritik Der Reinen Vernunft, B626.

48. Schürmann, "Legislation-Transgression," $394 \mathrm{n} 24$.

49. Schürmann, Broken Hegemonies, 672n154.

50. Kant, Kritik Der Reinen Vernunft, B626-67.

51. Kant, Kritik Der Urteilskraft, §76, 336.

52. Broken Hegemonies, 506.

53. Ibid., 485, 95-6.

54. Kant, Kritik Der Reinen Vernunft, B157.

55. Broken Hegemonies, 496.

56. Kant, Kritik Der Reinen Vernunft, B157n.

57. Schürmann appeals to a note in the Paralogisms section of the Doctrine of Elements in which Kant gestures to a heteronomous and fleeting sort of mental material that points to an existence that is neither an appearance nor a thing in itself. See Broken Hegemonies, 497. Kant there speaks of an indeterminate perception of "something real, which was given, and indeed only to thinking in general, thus not as appearance, and also not as a thing in itself (noumenon), but rather as something that in fact exists and is indicated as an existing thing in the proposition 'I think." See, Kant, Kritik Der Reinen Vernunft, B423.

58. Broken Hegemonies, 498.

59. Schürmann insists that the pathological should not be confused with the original pathos that names the irreducible suffering endemic to encounters with the singular. To call transcendental legislation "pathological" is to recognize it as bound to this originary suffering. To speak of the "pathology of being" is to articulate the pathos endemic to the manner in which being comes to language.

60. Broken Hegemonies, 504.

61. Agamemnon, 206-11.

62. Broken Hegemonies, 505.

63. Rodolphe Gasché has suggested that Schürmann's thinking, particularly his emphasis on the way in which "fantasms" operate hegemonically by obsessively maximizing a particular phenomenon or representation in a way that obscures all others, "suggests a psychoanalytic reading" (Gasché, "Hegemonic Fantasms," 313). It is doubtful that Schürmann himself would have embraced such a reading.

64. See Sigmund Freud, The Ego and the Id, The Standard Edition of the Complete Psychological Works of Sigmund Freud, 24 vols. (London: Hogarth Press, 1955), XIX, 15. See too, Richard Wollheim, Sigmund Freud (New York: Viking Press, 1971), 176.

THE VOICE OF SINGULARITY 
65. See Freud, The Ego and the Id, 16n. See too, Wollheim, Sigmund Freud, 180.

66. Broken Hegemonies, 482.

67. Ibid., 505.

68. Cf, Ibid., 22. See too, p. 5, above.

69. At the very end of Broken Hegemonies, Schürmann gestures to the way of thinking and philosophical saying associated here with natality, but he segregates natality from this other thinking and saying: "The analytic of ultimates holds forth upon the hegemonic fantasms, but an epilogue to fantasms as such is literally unthinkable, just as it is unthinkable not to enlist univer- sals into the service of some consoling and consolidating noun. All common nouns are capable of this, for we think and speak under the fantasmogenic impetus of natality. It is, however, possible to enlarge one's way of thinking beyond the fantasied common. In our languages, verbs in the middle voice always lead their speaker out of simple nominative lawmaking. It is, then, possible to think for itself the double bind that we know" (ibid., 631).

70. Schürmann writes, "Mortality familiarizes us with our singularization to come" (ibid., 19; see also 14).

The Pennsylvania State University, University Park, PA 16802 